PERSONAL BRANDING OF HOMESCHOOLING TEACHER

\title{
PENGALAMAN KOMUNIKASI GURU HOMESCHOOLING
}

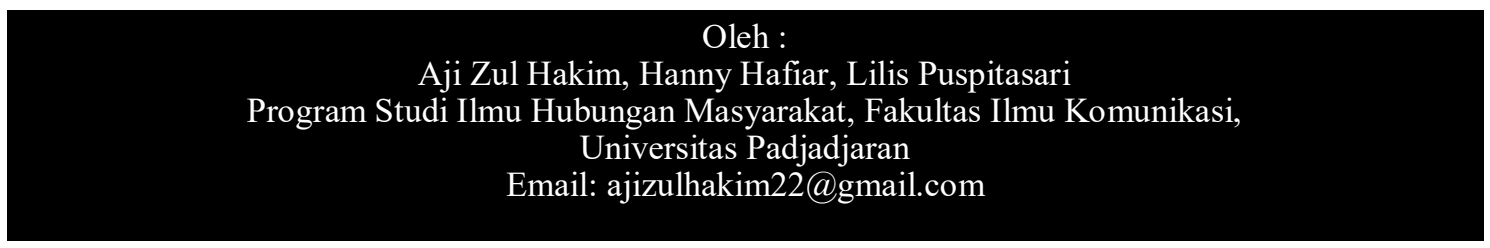

Abstract. Homeschooling is an alternative education model for child who find it less suited to formal school. In the development of this model reap the pros and cons in the society. Various attemps were made by institutions and association to change the paradigm of society, on of them by optimizing the role of teacher. Research with phenomenological approach is sought to know the communications behavior of homeschooling teacher. Eight teacher from four homeschooling institutions are involved through some in-depth interviews. In addition, data collection is done through participant obersvation and study of literature. The result showed the meaning of homeschooling affected by their experience in teaching, which affects their act in the form of personal branding, including their communications behaviour in contributing to the socialization of homeschooling.

Key words: Personal Branding, Communications Behavioral, Homeschooling Teacher

Abstrak. Homeschooling merupakan model pendidikan alternative bagi anak yang merasa kurang cocok dengan sekolah formal. Dalam perkembangannya model pendidikan ini menuai pro dan kontra di masyarakat. Berbagai upaya dilakukan oleh lembaga dan asosiasi untuk merubah paradigma masyarakat, salah satunya dengan optimalisasi peran guru. Penelitian dengan pendekatan fenomenologis ini berupaya mengetahui perilaku komunikasi Guru Homeschooling. Delapan orang Guru Homeschooling dari empat lembaga di Kota Bandung dilibatkan melalui wawancara mendalam. Selain itu, pengumpulan data dilakukan melalui observasi partisipatif dan studi kepustakaan. Hasil penelitian menunjukan pemaknaan homeschooling oleh guru dipengaruhi pengalaman mereka selama mengajar, yang mempengaruhi tindak lanjut mereka dalam membentuk personal branding, termasuk perilaku komunikasi mereka dalam berkontribusi pada sosialisasi homeschooling.

Kata kunci: Personal Branding, Perilaku Komunikasi, Guru Homeschooling

\section{A. PENDAHULUAN}

Homeshcooling hadir sebagai alternatif pendidikan menurut Sanny Darman, pertama, adanya kesadaran orang tua bahwa tanggung jawab pendidikan tidak bisa diberikan ke sekolah. Orang tua mulai menyadari bahwa sekolah tidak menjawab seluruh kebutuhan pendidikan, bagaimanapun kesuksesan seorang anak itu dari keluarga. Kedua, makin menyadari tiap anak itu berbeda dan tidak bisa diseragamkan cara belajarnya, kondisi yang sering ditemui adalah anak tidak merasa nyaman dalam belajar. Ketiga, semakin disadari akademis saja tidak sepenuhnya menjawab kebutuhan. Anak membutuhkan skill atau bakat yang harus mereka keluarkan. Menyadari persaingan ijazah itu mudah sekali, tetapi yang terpenting adalah skill yang harus diketahui dan diasah sedini mungkin.

Perkembangan homeschooling men- 
jadi salah satu alternatif pendidikan dalam perjalanannya juga menuai pro dan kontra, bahkan hingga saat ini. Karena homeschooling berkaitan dengan pendidikan dan orang tua pasti menginginkan pendidikan yang terbaik bagi anaknya. Hal ini juga ditanggapi oleh Sanny Darman selaku Ketua Asosiasi Sekolah Rumah dan Pendidikan Alternatif Kota Bandung.

"Jadi memang masih banyak yang kontra, karena bagaimanapun kita dibesarkan dan dididik dengan sekolah formal, jadi mengubah paradigma itu tidak mudah. Banyak yang dipertanyakan, mulai dari ujian, tidak diterima di universitas negeri, anak tidak belajar, kalah bersaing dengan sekolah formal, orang tua tidak bisa ngajar."

Dari pernyataan Sanny Darman, tidak semua orang mudah dalam menerima perubahan. Tidak dipungkiri bahwa hampir kita semua termasuk orang tua kita dibesarkan dan dididik dengan sekolah formal. Pertanyaan pun terus mengalir dari orang tua mulai dari ujian, legalitas, hingga kapasitas orang tua dalam mengajar anak.

Berbagai upaya dilakukan lembaga untuk menarik calon siswa dan juga orang tua agar percaya dan memahami bagaimana model serta implementasi dari homeschooling. Tujuan utamanya adalah merubah paradigma orang tua bahwa sekolah itu tidak hanya sekolah formal. Upaya yang dilakukan lembaga antara lain membuat sebuah event festival homeschooling di pusat keramaian seperti mall, mengadakan parents meeting, promosi menggunakan berbagai media, membuat sebuah seminar, open house, word of mouth dan masih banyak lagi lainnya

Lembaga-lembaga homeschooling ini tergabung dalam sebuah asosiasi bernama Asosiasi Sekolah Rumah dan Pendidikan Alternatif. Fungsi dari asosiasi ini adalah menjadi jembatan antara lembaga dengan pemerintah serta masyarakat. Peneliti mengamati bahwa masingmasing lembaga saling membantu untuk menciptakan market homeschooling khususnya di Kota Bandung. Hal ini dapat dilihat dari seringnya pertemuan antara lembaga dalam acara asosiasi untuk membahas perkembangan seputar homeschooling.

Dalam rangka mengkomunikasikan pesan kepada masyarakat umum dan orang tua murid, peneliti menemukan bahwa lembaga juga memberikan peran lebih kepada guru. Peran yang di dapat guru adalah sebagai agen komunikasi kepada masyarakat. Hal ini kemudian 
diperkuat oleh statement Sanny Darman.

"Kemasyarakat biasanya mereka ditanya guru mana, mau ga mau harus menjadi agen komunikasi. Karena itu begitu masuk pasti kita berikan informasi dulu mengenai homeschooling karena kalau diluar pasti ditanya kan. Nah mereka yang harus menjelaskan. Minimal prinsip-prinsipnya mereka tahu."

Dalam menjalankan perannya sebagai agen komunikasi, guru homeschooling mendukung lembaga dalam melakukan sosialisasi homeschooling di Kota Bandung. Upaya yang dilakukan guru homeschooling adalah membantu lembaga dalam mengedukasi masyarakat mengenai model pendidikan alternatif bernama homeschooling. Publik yang menjadi kunci adalah orang tua karena orang tua lah yang memiliki peran besar dalam memilih pendidikan untuk anaknya.

Di homeschooling, khususnya komunitas atau di lembaga, tempat dan suasana belajar mengajar dikondisikan senyaman mungkin layaknya anak berada di rumah. Namun, kurikulum yang diterapkan sama dengan sekolah formal, dengan tujuan penyamaan lulusan. Perbedaan lainnya adalah sekolah dilaksanakan minimal dua kali dalam sem- inggu disesuaikan dengan permintaan dan kebutuhan, waktu pengajaran pun hanya dua jam sehari. Sisanya anak diwajibkan belajar dirumah atau dapat mengembangkan minat dan bakat dengan pengawasan orang tua.

Waktu pertemuan yang lebih singkat dibanding dengan proses belajar mengajar di sekolah formal membuat guru homeschooling membutuhkan keahlian khusus dalam mengemas materi pelajaran. Tantangan lainnya adalah melakukan proses belajar mengajar yang membuat anak nyaman dalam belajar serta menyembuhkan anak yang memiliki trauma dalam bersekolah sehingga membedakan model pendidikan ini dengan sekolah formal. Hal ini diperkuat oleh pernyataan Sanny Darman.

$$
\begin{aligned}
& \text { "Guru yang dibutuhkan ada- } \\
& \text { lah guru yang mau belajar } \\
& \text { mengerti anak. Dibanding } \\
& \text { sekolah formal yang harus seperti } \\
& \text { ini dan itu kalau di homeschool- } \\
& \text { ing mereka harus lebih kreatif } \\
& \text { berpikir out of the box" } \\
& \text { Dari pernyataan Sanny Darman, hal } \\
& \text { penting yang harus dipahami oleh guru } \\
& \text { homeschooling adalah mengerti anak, } \\
& \text { bahwa tiap anak memiliki keunikan dan } \\
& \text { sifat masing-masing yang tidak bisa } \\
& \text { disamakan seperti disekolah formal. }
\end{aligned}
$$


Selain itu, guru homeschooling juga harus kreatif agar anak nyaman dalam belajar serta terus membangkitkan motivasinya dalam belajar dan mengembangkan minatnya.

Dalam proses belajar mengajar yang dilakukan di lembaga, peneliti menemukan perbedaan cara mengajar yang dilakukan oleh guru homeschooling dibanding dengan guru sekolah formal. Seperti yang diungkapkan oleh Adi yang merupakan guru homeschooling di Taman Sekar Bandung.

"Pertama saya memposisikan seperti seorang kakak terhadap adek, ya hubungannya tidak formal, santai. Mungkin itu yang diterima anak-anak disini adalah kenyamanan. Saya bangun kenyamanan bahwa saya disini adalah tutor atau guru, tapi diluar itu ya anggaplah sebagai kakak sendiri. Anggaplah seseorang yang nyaman diajak ngobrol dan bercanda. Itu yang selama ini saya jalani, saya tidak pengen selalu dihormat."

Dengan memposisikan sebagai kakak tentu sudah menjadi hal yang berbeda dengan guru sekolah formal. Kondisi yang dibangun mencoba membentuk suasana belajar yang senyaman mungkin.
Dengan menempatkan diri sebagai kakak, tentu gap antara guru dan siswa tidak seperti di sekolah formal. Hal ini yang diyakini dapat membuat anak merasa nyaman dalam melakukan pembelajaran. Berikut pendapat salah satu anak yang pindah dari sekolah formal ke homeschooling.

"Nyaman banget kak, ga kaya dulu disekolah formal dikit-dikit dimarahin, kadang bukan aku yang salah aku ikut dimarahin. Kalau disini gurunya kayak temen, terus aku curhat masalahku gimana dan mereka mengerti dan aku merasa diterima apa adanya.

Dengan pendekatan yang berbeda anak merasa lebih diterima dibanding dengan sekolah sebelumnya. Anak pun dapat menceritakan masalah yang mereka alami dengan gurunya yang tidak bisa dilakukan kepada guru sekolahnya terdahulu atau bahkan ke orang tuanya.

Mayoritas anak yang mengikuti model homeschooling memiliki berbagai latar belakang sehingga memilih homeschooling. Beberapa ada yang tidak cocok atau memiliki masalah di sekolah formal. Masalah-masalah yang dialami anak biasanya memiliki kesibukan lain dalam menekuni minat dan bakatnya. Adapula yang memiliki masalah dengan 
tenaga pendidik atau menjadi korban bullying.

Orang tua akhirnya mendapatkan alternatif bagi anaknya yang merasa tidak cocok dengan pendidikan sekolah formal. Anak pun tetap mendapatkan haknya untuk memperoleh pendidikan layaknya anak yang lain. Seperti yang diungkapkan oleh salah satu orang tua siswa homeschooling.

"Ya gimana anak saya itu kan kondisinya seperti itu beda dengan yang lain. Kalau disekolah malah sering dimarahin gurunya karena nakal. Akhirnya dia nya malah sering bolos sekolah karena capek dimarahin terus. Kalau di homeschooling saya lihat dia bisa seneng belajar terus lebih terbuka sama saya tentang permasalahan yang dialaminya."

Homeschooling nyatanya dapat membantu orang tua yang sedang mencari alternatif ketika kondisi anak sudah tidak mau bersekolah. Nilai positif lain yang didapatkan adalah karena basic nya homeschooling adalah pendidikan keluarga, anak pun dapat lebih terbuka terhadap permasalahan yang mereka alami. Hubungan antara orang tua dan anak kemudian menjadi semakin intim. Ber- dasarkan hal tersebut menjadi penting kiranya dilakukan sebuah riset yang mengkaji mengenai komunikasi guru homeschooling. Oleh karena itu tulisan ini bermaksud untuk mengungkap hal yang berkaitan dengan dengan pengalaman komunikasi guru homeschooling dengan lingkungannya.

1. Landasan Teori

Teori yang digunakan dalam penelitian ini adalah teori fenomenologi transcedental yang dicetuskan oleh Edmund Husserl. Bagi Husserl, fenomenologi adalah ilmu fundamental dalam berfilsafat. Fenomenologi adalah ilmu tentang hakikat dan bersifat a priori (Munir, Misnal, dalam Kuswarno, 2009:9)

Husserl berpendapat bahwa ilmu positif memerlukan pendamping pendekatan filasafat fenomenologis. Pemahamannya diawali dengan ajakan kembali pada sumber atau realitas yang sesunggunya. Untuk itu, perlu langkahlangkah metodis "reduksi" atau menempatkan fenomena dalam keranjang (bracketing) atau tanda kurung. Melalui reduksi, terjadi penundaan upaya menyimpulkan sesuatu dari setiap prasangka terhadap realitas. Adapun langkahlangkah metodis yang dimaksud adalah reduksi eidetis, reduksi fenomenologi, dan reduksi transedental (Basrowi. 
2002:34)

Dengan menempatkan fenomena dalam tanda kurung, berarti kita menempatkan perhatian kita dalam struktur pengalaman sadar. Kata kuncinya adalah membedakan apakah kesadaran itu bagian dari kesengajaan, ataukah karena terhubung langsung dengan sesuatu. Misalnya kesadaran kita akan sebatang pohon, dengan menempatkan pohon dalam tanda kurung, maka perhatian kita tidak harus kepada pohon secara spesifik, namun bisa pada pohon dan makna pohon yang ada dalam struktur pengalaman kita. Inilah yang oleh Husserl dinamakan dengan pengertian noema dan noematic dari pengalaman.

Melalui reduksi transedental, Husserl menemukan adanya esensi kesadaran yang disebut intensionalitas. Setiap aktivitas intensionalitas (noetic) termasuk aktivitas menyadari sesuatu. Pengertian kesadaran selalu dihubungkan dengan kutub objektifnya, yakni objek yang disadari (Basrowi, 2002:34). Hal yang paling penting dalam reduksi ini bukan terletak pada persoalan menempatkan fenomena dalam tanda kurung, melainan bagaimana subjek memberikan interpretasi terhadap objek selanjutnya (Munir, 2008:90-93).

Setiap subjek transedental mengkonsitustikan dunianya sendiri, menurut perpektifnya sendiri yang unik dan khas. Dunia tidak dipahami sebagai dunia objektif dalam pengertian fisik material, tetapi dunia sebagaimana dihayati oleh subjek sebagai pribadi. Dengan demikian dalam pandangan fenomenologi, dunia itu subjektif dan relatif. Tugas fenomenologilah untuk menggali dunia yang dihayati tersebut, sehingga hasilnya dapat dijadikan sebagai asumsi ilmu pengetahuan (Basrowi, 2002: 35)

Adapun pokok-pokok pikiran Husserl (Munir, 2008: 90-93) mengenai fenomenologi, adalah sebagai berikut ini:

a. Fenomena adalah realitas sendiri yang tampak.

b. Tidak ada batas antara subjek dengan realitas

c. Kesadaran bersifat intensional.

d. Terdapat interaksi antara tindakan kesadaran (noesis) dengan objek yang disadari (noema).

2. Konsep Pengalaman Komunikasi

Memori memegang peranan penting dalam mempengaruhi persepsi maupun berpikir. Kemudian, menyebabkan organisme sanggup merekam fakta tentang dunia dan menggunakan pengetahuannya untuk membimbing perilakunya. (Schlessinger \& Groves, 1976 dalam Rakhmat, 2008: 62). Pengalaman merupakan sesuatu yang dialami. Melalui pengalaman, individu memiliki penge- 
tahuan. Hal ini sesuai dengan pernyataan bahwa: "All objects of knowledge must conform to experience" (Moustakas, 1994: 44).

Pengalaman individu terkait suatu obyek atau peristiwa berhubungan dengan fenomena yang dialami individu berhubungan dengan obyek atau peristiwa itu. Hal ini diterangkan oleh Radford (2005: 151) yang mengatakan "People is retrieving a memory of a prior experience of phenomena" yang berarti bahwa setiap orang menyimpan memori dari pengalaman dalam fenomena sebelumnya.

Setiap fenomena yang dilihat atau dialami individu tersimpan dalam ruang kesadaran diri individu dan berwujud sebagai pengalaman individu itu sendiri. Pengalaman bisa berhubungan dengan banyak dimensi dan sisi kehidupan individu termasuk komunikasi. Setiap individu pasti memiliki pengalaman dalam berkomunikasi dengan individu lain. Pengalaman komunikasi individu bersifat relatif dan subjektif.

Melalui penjelasan tersebut, maka dapat dijelaskan bahwa pengalaman komunikasi yang dimaksud dalam penelitian ini adalah sesuatu yang dialami individu dan berkaitan dengan aspekaspek komunikasi, melalui proses, simbol maupun makna yang dihasilkan, serta dorongannya pada tindakan. Maka pengalaman komunikasi yang dialami oleh guru homeschooling saat mereka berhadapan dengan homeschooler, menimbulkan sebuah tindak lanjut yang mereka lakukan. Salah satu tindak lanjut tersebut adalah menjadi sosok guru yang disukai oleh anak-anak.

\section{Konsep Proses Belajar Mengajar}

Oemar Hamalik (2005: 154) mendefinisikan belajar adalah perubahan tingkah laku yagn relatif mantap berkat latihan dan pengalaman. Belajar merupakan suatu aktivitas yang menimbulkan perubahan yang relatif permanen sebagai akibat dari upaya-upaya yang dilakukannya. Mengajar adalah penciptaan sistem lingkungan yang memungkinkan terjadinya proses belajar (JJ. Hasibuan dan Moedjiono, 2002: 3).

Menurut (Martinis Yamin, 2007: 59), proses belajar mengajar merupakan proses yang sistematik, artinya proses yang dilakukan oleh guRu dan siswa di tempat belajar dengan melibatkan sub-sub, bagian, komponen-komponen atau unsurunsur yang saling berinteraksi untuk mencapai suatu tujuan.

\section{Konsep Homeschooling}

Dalam bahasa Indonesia, terjemahan dari homeschooling adalah "sekolah rumah". Istilah ini dipakai secara resmi oleh Departemen Pendidikan Nasional 
(Depdiknas) untuk menyebutkan homeschooling. Selain sekolah rumah, homeschooling terkadang diterjemahkan dengan istilah sekolah mandiri.

Homeschooling merupakan model pendidikan alternatif selain di sekolah.. Pengertian umum homeschooling adalah model pendidikan di mana sebuah keluarga memilih untuk bertanggung jawab sendiri atas pendidikan anakanaknya. Di dalam penyelenggaraan homeschooling, orang tua dapat memilih apakah menyelenggarakan sendiri proses homeschooling atau mereka menggunakan bantuan lembaga lain, baik sedikit atau banyak di dalam proses penyelenggaraan. Lembaga yang sering disebut dengan istilah homeschooling, sebenarnya sebutan lengkapnya adalah Komunitas Homeschooling. Lembaga ini memberikan layanan dan bantuan di dalam penyelenggaraan homeschooling. (Sumardiono, 2010: 7).

Bentuk layanan dalam komunitas homeschooling berbeda antara satu dengan lainnya, demikian juga biayanya. Ada komunitas yang hanya memberikan layanan asistensi kurikulum, proses belajar, dan ujian tanpa menyediakan tutor/ pengajar karena semua proses belajar diserahkan sepenuhnya pada keluarga. Ada komunitas yang juga menyediakan layanan tutor yang datang ke rumah, ada komunitas yang melakukan pertemuan rutin beberapa kali dalam satu minggu. (Sumardiono, 2007:7).

\section{Konsep Personal Branding}

"Personal branding is the process of developing a "mark" that is created around your personal name or your career. You use this "mark" to express and communicate your skills, personalty, and values. The end goal is that the personal brand that you develop will build your reputation and help you to grow your network in a way that interest others. They will then seek you out for your knowledge and expertise."

Apabila pengertian diatas dikaitkan dengan penelitian ini, bagaimana seorang guru homeschooling mengembangkan ciri khas dalam dirinya. Guru homeschooling menggunakan ciri khas nya untuk mengekspresikan dan mengkomunikasikan skills, personaliti, dan nilainilai yang ada pada dirinya. Tujuannya untuk membangun reputasi dan mengembangkan karir mereka.

"A personal brand is the total experience of someone having a relationship with who you are and what you represent as an individual."

Dari pengertian di atas peneliti menyimpulkan, personal branding adalah pengalaman dari guru homeschooling dalam menjalankan hubungan dengan dirinya sendiri dan apa yang diperlihatkan sebagai individu. Berkaitan dengan 
penelitian ini adalah pengalaman komunikasi apa saja yang dialami oleh guru homeschooling dalam membentuk personal branding.

Personal brand juga dapat menjadi cerminan bagi lembaga tempat individu bernaung. Ketika konsumen mengasosiasikan produk tertentu dengan sebuah perusahaan tertentu, mereka cenderung menganggap korporasi lebih positif. Personal brand yang kuat merefleksikan nilai baik lembaga maupun individu. (Schawbel, 2010: 53)

6. Metode Penelitian

Penelitian ini menggunakan metode kualitatif. John Creswell (1998:15) menjelaskan bahwa penelitian ini sebagai sebuah proses penelitian yang mengeksplorasi masalah sosial dan manusia. Peneliti membangun gambaran yang kompleks dan menyeluruh, menganalisis kata-kata, melaporkan secara detail pandangan responden dan melakukannya dalam sebuah setting penelitian yang naturalis. Sedangkan pendekatan yang digunakan dalam penelitian ini adalah pendekatan fenomenologis, dimana pendekatan ini menurut Polkinghorne (Creswell, 1998: 51-52) menggambarkan arti sebuah pengalaman hidup untuk beberapa orang tentang sebuah konsep atau fenomena. Orang-orang yang terlibat da- lam menangani sebuah fenomena melakukan eksplorasi terhadap struktur kesadaran pengalaman hidup manusia.

Menurut Husserl (Creswell, 1998: 52) peneliti fenomenologis berusaha mencari tentang, hal-hal yang perlu (esensial), struk invarian (esensi) atau arti pengalaman yang mendasar dan menekankan pada intensitas kesadaran dimana pengalaman terdiri dari hal-hal yang tampak dari luar dan hal-hal yang berada dalam kesadaran masing-masing berdasarkan memori, image, dan arti.

Dalam penelitian ini paradigma yang dijadikan rujukan adalah paradigma konstruktivisme. Konstruktivisme merupakan paradigma yang toleran, longgar serta tidak terlalu mementingkan tahap penelitian. Paradigma ini melahirkan metode penelitian kualitatif yang memiliki sifat sangat berbeda dengan kuantitatif. Realitas memiliki sifat relatif, yang merupakan hasil dari konstruksi mental yang bermacam-macam dan tak dapat diindra (Denzin dan Lincoln, 2009:107.). Realitas dibentuk oleh pengalaman dan konstruksi sosial yang berlaku. Selain itu, realitas juga berciri lokal dan spesifik dan bentuk serta isinya bergantung pada manusia atau kelompok sosial yang memiliki konstruksi tersebut. Tidak ada unsur generalisasi dalam penciptaan realitas. Dan muncul istilah realitas 
majemuk yang merupakan simplifikasi dari banyaknya jumlah realitas yang tercipta.

Pengumpulan data dalam penelitian ini dilakukan melalui wawancara mendalam, observasi, dan studi pustaka. Wawancara mendalam yang dilakukan secara semi-structured interview, dimana peneliti memiliki satu daftar pertanyaan atau topik spesifik yang akan dibahas tetapi informan memiliki kebebasan untuk menjawa pertanyaan. Observasi dilakukan ketika wawancara berlangsung, termasuk dari cara informan menjawab pertanyaan, serta mengamati bagaimana gesture Guru Homeschooling yang diperlihatkan selama wawancara. Studi pustaka diperlukan penulis sebagai bukti pendukung untuk mengetahui data-data sekunder.

Uji keabsahan data dalam penelitian ini dilakukan dengan triangulasi data yang diperoleh dengan melakukan wawancara dalam waktu yang berbeda, juga membandingkan keadaan dan perspektif seseorang dengan berbagai pendapat dan pandangan orang lain. Triangulasi sumber dalam penelitian ini adalah Ketua Asosiasi Sekolah Rumah dan Pendidikan Alternatif (ASAHPENA) Kota Bandung, yaitu Sanny Darman.

\section{B. HASIL DAN PEMBAHASAN}

Pertanyaan kedua mengenai pengalaman komunikasi guru homeschooling dalam membentuk personal branding saat proses belajar mengajar. Fenomenologi membantu peneliti memasuki sudut pandang orang lain dan berupaya memahami mengapa mereka menjalani hidupnya dengan cara seperti itu. (Daymon dan Hallowaym 2008: 228 dalam Ardianto, 2011: 66).

Personal branding merupakan persepsi yang tertanam dan terpelihara dalam benak orang lain, maka yang menjadi inti persoalannya adalah bagaimana orang lain memandang seseorang tersebut pada sisi positif dan tertarik untuk menggunakan jasanya (Parengkuan \& Tumewu, 2014: 18). Upaya pemaknaan yang dilakukan informan tentu berdampak kepada persepsi anak terhadap dirinya. Schutz meletakkan hakikat manusia dalam pengalaman subjektif, terutama ketika mengambil tin-dakan dan mengambil sikap terhadap dunia kehidupan sehari-hari (Artawan, Shintadewi, \& Budiana, 2016). Hasil pemaknaan tersebut juga berdampak kepada eksistensi informan di masyarakat mengingat model homeschooling belum sepenuhnya diterima di masyarakat. 


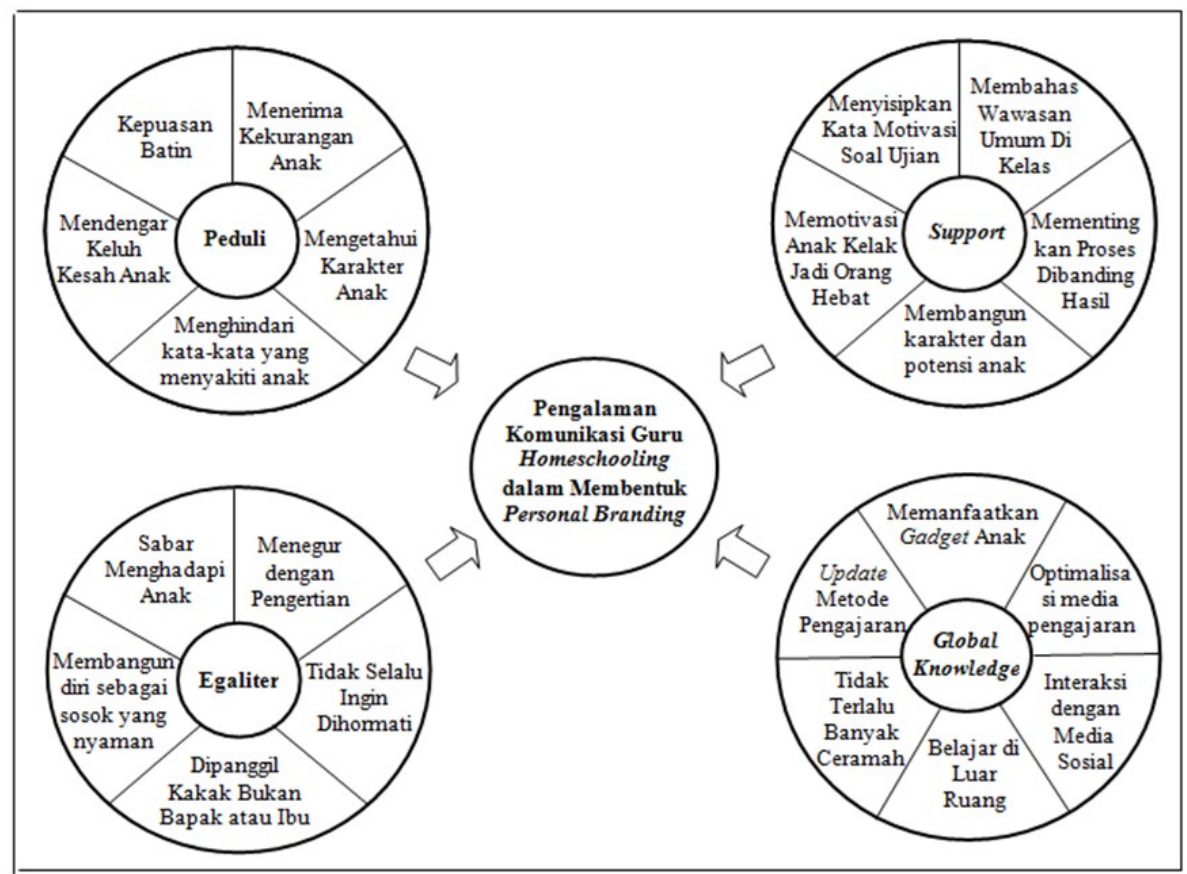

Model 1.1 Pengalaman Komunikasi Guru Homeschooling Dalam Membentuk Personal randing

Pengalaman komunikasi yang dialami guru homeschooling ketika mereka berhadapan dengan siswa saat proses belajar mengajar. Pengalaman komunikasi yang dimaksud adalah sesuatu yang dialami individu dan berkaitan dengan aspek-aspek komunikasi, melalui proses, simbol, maupun makna yang dihasilkan serta dorongannya pada tindakan. Tindakan yang dimaksud adalah untuk menjadi sosok guru yang disukai oleh muridnya. Peneliti menggolongkan personal branding Guru Homeschooling menjadi empat jenis, yaitu peduli, egaliter, support, dan global knowledge.

Pengalaman komunikasi guru yang peduli meliputi mementingkan kepuasan batin dalam mengajar dibanding dengan materi, menerima segala kekurangan yang dimiliki anak, tidak mengeluarkan kata-kata yang menyakiti hati anak, mendengarkan keluh kesah anak, memberi tahu mana yang baik dan buruk bagi anak, dan mengetahui karakteristik masing-masing anak.

Pengalaman komunikasi menjadi guru yang peduli, sering kali kita jumpai kondisi dimana anak mengeluh karena merasa tidak ada yang peduli dengan permasalahan yang mereka hadapi, baik dirumah maupun disekolah. Tuntutan orang tua akan nilai yang bagus dan guru yang hanya menyuruh kita belajar dan mengerjakan tugas. Hal tersebut menjadi motivasi tersendiri bagi informan untuk menjadi sosok yang dibutuhkan oleh 
anak-anak. Informan memandang anak lebih penting daripada pelajaran, menyadari bahwa tugas mereka adalah menyediakan sebuah lingkungan yang nyaman. Mengembangkan hubungan yang erat dengan murid, mengengarkan keluh kesah mereka, memperlihatkan empati serta memenuhi kebutuhan akademik dan emosional murid.

Pengalaman komunikasi menjadi guru yang peduli juga dapat dikategorikan sebagai komunikasi antar pribadi bersifat empati. Yaitu merasakan apa yang dirasakan orang lain. Komunikasi antar pribadi dapat berlangsung kondusif apabila komunikator (pengirim pesan) menunjukan rasa empati pada komunikan (penerima pesan). Sugiyo (2005), empati dapat diartikan sebagai menghayati perasaan orang lain atau turut merasakan apa yang dirasakan orang lain. Sementara Surya dalam Sugiyo (2005) mendefinisikan bahwa empati adalah sebagai suatu kejadian untuk memahami orang lain secara paripurna, baik yang nampak maupun yang terkandung, khususnya dalam aspek perasaan, pikiran, dan keinginan. Individu dapat menepatkan diri dalam suasana perasaan, pikiran, dan keinginan orang lain sedekat mungkin apabila individu tersebut dapat berempati. Apabila empati tersebut tumbuh dalam proses komunikasi antar pribadi maka suasana hubungan komunikasi akan dapa berkembang dan tumbuh sikap saling pengertian dan penerimaan. Empati tidak saja berkaitan dengan aspek kognitif, tetapi mengandung aspek afektif, dan ditunjukan dalam gerakan seperti cara berkomunikasi. (Hidayat, 2012: 46-47)

Pengalaman komunikasi guru yang egaliter meliputi penggunaan kata kakak sebagai panggilan bukan bapak atau ibu, menjadi seseorang yang nyaman diajak berbicara dan bermain, tidak ingin selalu dihormati, sabar dalam menghadapi anak yang kelewat batas, dan menegur dengan pengertian bukan dengan hukuman.

Pengalaman komunikasi menjadi guru yang egaliter, menurut Kamus Besar Bahasa Indonesia (2001: 285), egalitarian adalah pandangan atau doktrin yang menyatakan bahwa manusia itu ditakdirkan sama derajat. Di dalam lingkungan homeshcooling informan menganggap dirinya sebagai sosok kakak atau teman yang dapat membuat anak nyaman untuk diajak berbicara. Hubungan yang dijalin adalah layaknya kakak dan adik yang belajar bersama. Patut dipahami pula bahwa komunikasi verbal dan nonverbal, merupakan varian dari komunikasi antarpribadi. (Supratman \& Rafiqi, 2016).

Pengalaman komunikasi menjadi 
guru yang egaliter juga dapat dikategorikan sebagai komunikasi antar pribadi bersifat kesetaraan atau kesamaan. Yaitu pengakuan secara diam-diam bahwa kedua belah pihak menghargai, berguna, dan mempunyai sesuatu yang penting untuk disumbangkan. Kesetaraan merupakan perasaan sama dengan orang lain, sebagai manusia tidak tinggi atau rendah, walaupun terdapat perbedaan dalam kemampuan tertentu, latar belakang keluarga atau sikap orang lain terhadapnya. Rakhmat (2005) mengemukakan bahwa persamaan atau kesetaraan adalah sikap memperlakukan orang lain secara horizontal dan demokratis, tidak menunjukkan diri sendiri lebih tinggi atau lebih baik dari orang lain karena status, kekuasaan, kemampuan, intelektual kekayaan atau kecantikan. Dalam persamaan tidak mempertegas perbedaan, artinya tidak menggurui, tetapi berbincang pada tingkat yang sama, yaitu mengkomunikasiakan penghargaan dan rasa hormat pada perbedaan pendapat merasa nyaman, yang akhirnya proses komunikasi akan berjalan dengan baik dan lancar. (Hidayat, 2012: 49)

Pengalaman komunikasi guru yang support meliputi membuat kata sisipan yang memotivasi di tiap lembar soal ujian, membahasa wawasan umum di sela-sela jam pelajaran, mementingkan proses pembelajaran dibanding dengan hasil, selalu memberikan motivasi kepada anak kelak akan menjadi orang yang hebat atau sukses, membangun karakter anak, dan membantu mengembangkan potensi yang dimiliki oleh anak.

Pengalaman komunikasi menjadi guru yang support, menurut informan support yang diberikan seperti memberikan motivasi kepada murid agar mereka juga ikut termotivasi, karena tujuan dari homeschooling sendiri adalah memberikan motivasi belajar kepada anak. Motivasi belajar adalah keseluruhdan daya penggerak dalam diri siswa yang menimbulkan kegiatan belajar, yang menjamin kelangsungan dari kegiatan belajar dan memberikan arah pada kegiatan belajar, sehingga tujuan yang dikehendaki oleh subjek belajar itu dapat tercapai. (Sadirman, 1986: 75)

Pengalaman komunikasi menjadi guru yang support juga dapat dikategorikan sebagai komunikasi antar pribadi bersifat dukungan. Yaitu situasi yang terbuka untuk mendukung komunikasi berlangsung efektif. Dalam komunikasi antarpribadi diperlukan sikap memberi dukungan dari pihak komunikator agar komunikan mau berpartisipasi dalam komunikasi. Hal senada dikemukakan Sugiyo (2005), dalam komunikasi antar pribadi perlu adanya suasana yang men- 
dukung atau memotivasi, lebih-lebih dari komunikator. Rahmat mengemukakan bahwa "sikap suportif adalah sikap yang mengurangi sikap defensif. Orang yang defensif cenderung lebih banak melindungi diri dari ancaman yang ditanggapinya dalam situasi komunikan daripada memahami pesan orang lain. Dukungan merupakan pemberian dorongan atau pengorbaran semangat kepada orang lain dalam suasana hubungan komunikasi. Karena itu, dengan adanya dukungan dalam situasi terebut, komunikasi antarpribadi akan bertahan lama karena tercipta suasana yang mendukung. (Hidayat, 2012: 47)

Pengalaman komunikasi guru yang global knowledge meliputi memanfaatkan gadget yang dimiliki anak dalam proses belajar mengajar, mempelajari dan menerapkan berbagai metode pembelajaran terkini, tidak terlalu banyak ceramah dalam pengajaran, proses belajar mengajar tidak harus di dalam ruangan, menggunakan berbagai macam teknologi komunikasi dalam pengajaran, memanfaatkan sosial media dalam berinteraksi dengan anak.

Meningkatkan dan memperluas wawasan global merupakan unsur penting untuk memahami masalah global. Menurut Makagiansar (Mimbar Pendidikan, 1989) agar dapat meningkatkan wa- wasan global, maka pendidikan memegang peranan penting. Melalui pendidikan maka seseorang harus mampu mengembangkan empat hal berikut: 1) Kemampuan mengantisipasi (anticipate), artinya pendidikan berusaha menyiapkan anak didik untuk dapat mengantisipasi perkembangan IPTEK. 2) Mengerti dan mengatasi situasi (cope), artinya dapat mengembangkan kemampuan dan sikap peserta didik untuk menangani dan berhadapan dengan situasi baru. (3) Mengakomodasi (acomodate), artinya dapat mengakomodasi perkembangan IPTEK yang pesat dan segala perubahan yang ditimbulkannya. (4) Me-re-orientasi (re-orient), artinya persepsi dan wawasan tentang dunia perlu diorientasikan kembali karena perkembangan IPTEK dan perubahan sosial yang cepat sehingga memperoleh wawasan yang semakin luas.

Pengalaman komunikasi menjadi guru yang global knowledge, dilatar belakangi kesadaran informan untuk mengikuti perkembangan jaman. Kondisi saat ini tentu berbeda dengan yang dialami guru ketika bersekolah, perkembangan teknologi dan juga era globalisasi menjadi tantangan tersendiri untuk menyiapkan lulusan yang berkualitas. Metode yang digunakan juga seharusnya mengikuti dengan kondisi saat ini. 
Menurut Sanny Darman, pekermbangan jaman sangat lah cepat, kemajuan teknologi sangat pesat, sekarang sudah era nya globalisasi. Guru-guru yang ada saat ini adalah jebolan tahun 70-80an. Kondisi tersebut tentu berbeda dengan kondisi saat ini. Anak-anak nantinya akan disiapkan untuk tahun 2020-an, jangan memakai metode terdahulu untuk jaman sekarang.

\section{SIMPULAN}

Berdasarkan hasil penelitian, pengalaman komunikasi yang dialami oleh para informan selama menjadi guru homeschooling dalam upaya membentuk personal branding antara lain pengalaman komunikasi menjadi guru yang peduli, guru yang egaliter, guru yang support, dan guru yang global knowledge. Personal branding dilakukan oleh guru homeschooling dalam menjawab kondisi pendidikan dan anak-anak yang memiliki trauma atau ketidak cocokan dengan guru di sekolah formal.

Saran dari penelitian ini adalah guru homeschooling membuat sebuah ikatan baik berbentuk organisasi atau komunitas. Dengan adanya wadah berkumpul para guru homeschooling dapat memiliki ruang untuk bertukar pikiran satu sama lain sehingga wawasan terus berkembang dan update serta eksistensi guru homeschooling lebih terlihat dan kuat di masyarakat.

\section{DAFTAR PUSTAKA}

Ardianto, Elvinaro. 2011. Metodologi Penelitian untuk Public Relations, Kuantitatif dan kualitatif. Bandung: Simbiosa Rekatama Media.

Aristi, N., \& Hafiar, H. (2014). Analisis Beban Kerja Tenaga Pendidik Dan Kependidikan Di Fakultas Y Universitas X. Jurnal Kajian Komunikasi, 2/1, 53-60.

Artawan, G. A. W. M., Shintadewi, E. A., \& Budiana, H. R. (2016). Makna Kegiatan Unilever Future Leaders League Bagi Para Peserta. Profesi Humas, 1(1), 1-11.

Basrowi dan Sukidin. 2002. Metode Penelitian Kualitatif Perspektif Mikro. Surabaya: Insan Cendekia.

Creswell, John W. 1998. Qualitative Inquiry And Research Design: Choosing Among Five Traditions. London: SAGE Publications.

Denzin, Norman K. and Lincoln, Yvonna S. 2009. Handbook of Qualitative Research. Yogyakarta: Pustaka Pelajar

Hamalik, Oemar. 2005. Kurikulum dan Pembelajaran. Jakarta: Bumi Akasara

Hasibuan, JJ dan Moerdiono. 2002. Proses Belajar Mengajar. Jakarta: Remaja Karya.

Hidayat, Dasrun. 2012. Komunikasi Antar Pribadi dan Medianya. Yogyakarta: Graha Ilmu

Kuswarno, Engkus. 2009. Metodologi Penelitian Komunikasi Fenomenologi, Konsepsi, Pedoman, dan Contoh Penelitiannya. Bandung: Widya Padjadjaran.

Moustakas, Clark. 1994. Phenomenological Research Methods. California: Sage Publication.

Munir, Misnal. 2008. Aliran-Aliran Utama Filsafat Barat Kontemporer. Yogyakarta: Lima. 
Parengkuan, Erwin dan Becky Tumewu. 2014. Personal Brand-Inc. Jakarta: PT. Gramedia Pustaka Utama.

Radford. Gary. P. 2005. On The Philoshopy of Communication. Belmont: Wadsworth

Rakhmat, Jalaluddin. 2008. Psikologi Komunikasi. Bandung: Remaja Rosdakarya

Schawbel, Dan. 2010. Build a Powerful Brand To Achieve Carrier Success Me. 2.0. Berskhire: Kaplan Publishing

Sumardiono. 2007. Homeschooling Lompatan Cara Belajar. Jakarta: PT. Elex Media Kompatindo.

Supratman, L. P., \& Rafiqi, A. (2016). Kajian etnografi komunikasi pada gaya berkomunikasi komunitas. Jurnal Kajian Komunikasi, 4/1, 1-9.

Yamin, Martinis. 2007. Strategi Pembelajaran Berbasis Kompetensi. Jakarta: GP Press

\section{Website:}

http://marketing.about.com/od/

marketingglossary/g/definition-ofpersonal-branding.htm http://www.forbes.com/sites/ glennllopis/2013/04/08/personalbranding-is-a-leadership-requirement-not -a-self-promotion-campaign/ \#168801af15c0

http://

kurniawan.staff.uii.ac.id/2008/08/22/

$\underline{\text { mengembangkan-kepedulian-guru/ }}$ 